Number 2

\title{
PENGARUH PENUNDAAN PEMERIKSAAN URIN TERHADAP JUMLAH LEUKOSIT PADA PENDERITA INFEKSI SALURAN KEMIH
}

\author{
Bunga Dewanti' ${ }^{1}$ I Gusti Agung Dewi Sarihati², Burhannuddin ${ }^{3}$ \\ 1,2,3 Jurusan Analis Kesehatan Denpasar \\ Email : dewisarihati@gmail.com
}

\begin{abstract}
:
Background : urine is the rest of the body's metabolism that is released through the process of urinalization. Urine examination aims to determine the condition of the kidney and other urinary tracts. Delays in examinations in the laboratory often occur resulting in disturbed urine stability.

Purpose : this study aims to determine the effect of delays on the number of urine leukocytes in patients with urinary tract infections.

Method : this research with posttest only control group design using four control and treatment groups each consisting of 9 samples. The control group is the result of urine examination which is examined before 30 minutes while the treatment group is the result of urine examination after 1, 2 and 3 hours since being collected.

Result : the results showed an average difference between the control and treatment groups, especially there was a significant reduction in the 3-hour delay group.

Coclusion : the delay in urinary examination for 3 hours affects the amount of urine leukocytes in patients with urinary tract infections
\end{abstract}

Keywords: urine leukocytes, delay in urine examination

\section{PENDAHULUAN}

Infeksi saluran kemih (ISK) merupakan infeksi yang paling umum terjadi di komunitas masyarakat bahkan di rumah sakit. Kasus ISK tertinggi terjadi pada anak-anak terutama pada perempuan karena pendeknya saluran kemih atau uretra dan lebih dekat dengan anus ${ }^{1}$, hanya $8 \%$ penderita menunjukkan gejala adanya infeksi saluran kemih. Biasanya pada urine pasien dengan infeksi saluran kemih akan ditemukan leukosit dalam jumlah rendah hingga tinggi tergantung pada seberapa besar luka yang menyebabkan infeksi di dalam saluran kemih. ${ }^{2}$

Urinalisa merupakan salah satu pemeriksaan yang berfungsi untuk memantau kondisi ginjal dan saluran kemih. Parameter yang paling diperhatikan pada pemeriksaan urinalisa metode uji carik celup berupa bakteri, leukosit, eritrosit, nitrit, dan protein. Parameter tersebut dianggap mampu menggambarkan kondisi ginjal dan saluran kemih. ${ }^{3}$ Untuk mendapat hasil yang baik maka variasi fase dalam preanalitik harus diidentifikasi dengan

Meditory | ISSN Online : 2549-1520, ISSN Cetak : 2338 - 1159, Vol. 7, No. 1, Juni 2019

HIm. 7 - 12, http://ejournal.poltekkes-denpasar.ac.id/index.php/M 
benar seperti tes yang diperlukan, pengumpulan (sampling), transportasi sampel untuk sampai ke laboratorium, penerimaan sampel yang datang, hingga bagaimana cara menyiapkan sampel di tahap pengujian karena bila tidak dilakukan dengan baik dapat menjadi sumber kesalahan yang sangat fatal. ${ }^{4}$ Tahapan pre-analitik yang tidak tepat mampu menurunkan angka hasil palsu menjadi hampir $20 \%$ dari suatu hasil pemeriksaan laboratorium sehingga menyebabkan kesalahan diagnosa. ${ }^{4}$ Menurut pengamatan langsung dari peneliti di laboratorium Rumah Sakit, urine tidak langsung diperiksa hanya didiamkan pada suhu ruang sekitar 1 sampai 1,5 jam setelah penampungan ke dalam wadahnya yang diakibatkan oleh banyaknya jumlah pasien atau tertundanya pengiriman sampel dari ruangan ke laboratorium. Bahkan ketika pasien sedang tidak banyak, urine dibiarkan hingga menumpuk dan ditunda selama hampir 2 jam. Dari permasalahan di atas, penulis tertarik untuk melakukan penelitian terkait pengaruh penundaan urine terhadap jumlah leukosit.

\section{METODE}

Penelitian menggunakan rancangan Posttest Only Control Group Design. Sampel diambil dari 9 orang pasien infeksi saluran kemih yang periksa di laboratorium BRSU Tabanan. Urin dibagi kedalam empat kelompok, kelompok pertama adalah kelompok kontrol yaitu pemeriksaan yang dilakukan sebelum 30 menit sedangkan tiga kelompok lainnya diberikan perlakuan berupa penundaan pemeriksaan salama 1 , 2 dan 3 jam. Metode pemeriksaan leukosit urine dilakukan secara mikroskopis dengan menggunakan preparat basah Hasil pemeriksaan urin keempat kelompok diuji dengan KruskalWallis dan dilanjutkan dengan uji MannWhitney $U$.

\section{HASIL DAN PEMBAHASAN}

Rata-rata tertinggi jumlah leukosit ditemukan pada kelompok kontrol sebesar 13,1 sel/LPB dengan standar deviasi 7,68 dan terendah pada penundaan 3 jam sebesar 7,2 sel/LPB dengan standar deviasi 5,93. 
Uji Kruskal-Wallis menunjukkan ada pengaruh penundaan terhadap jumlah leukosit pada pasien infeksi saluran kemih dengan nilai $p$ sebesar 0,034 . Pengaruh tersebut terjadi antara kelompok kontrol dengan penundaan pemeriksaan 3 jam dengan nlai $\mathrm{p}$ sebesar
0,021 pada uji Mann-Whitney $U$. Perbedaan rata-rata kelompok kontrol dan perlakuan dapat dilihat pada tabel 1 dan tabel 2.

Tabel 1. Perbedaan Rata-rata Kelompok Kontrol dan Perlakuan dengan Uji KruskalWallis

\begin{tabular}{llll}
\hline Perlakuan & Rata-rata & $\begin{array}{l}\text { Standar } \\
\text { Deviasi }\end{array}$ & $\begin{array}{l}\text { Uji Kruskal- } \\
\text { Wallis }(\boldsymbol{p})\end{array}$ \\
\hline Kontrol & 13,1 & 7,68 & \\
1 Jam & 11,1 & 7,06 & 0,034 \\
2 Jam & 9,1 & 6,77 & \\
3 Jam & 7,2 & 5,93 & \\
\hline
\end{tabular}

Tabel 2. Hasil Uji Mann-Whitney U Perbedaan Rata-rata Kelompok Kontrol dengan Perlakuan

$\begin{array}{ll}\text { Perlakuan } & \text { Uji Mann- } \\ & \text { Whitney } U(p)\end{array}$

\begin{tabular}{ll}
\hline Kontrol dengan penundaan 1 jam & 0,181 \\
Kontrol dengan penundaan 2 jam & 0,051 \\
Kontrol dengan penundaan 3 jam & 0,021
\end{tabular}

Keterangan : Kontrol merupakan hasil pemeriksaan leukosit urine sebelum 30 menit

Infeksi saluran kemih (ISK) sering ditemukan pada wanita maupun merupakan gangguan berupa infeksi yang pria dengan gejala klinis yang berbeda-

Meditory | ISSN Online : 2549-1520, ISSN Cetak : 2338-1159, Vol. 7, No. 1, Juni 2019

HIm. 7 - 12, http://ejournal.poltekkes-denpasar.ac.id/index.php/M 
beda. $^{5} \quad$ Penegakan diagnosa infeksi saluran kemih secara laboratorium dapat dilihat pada parameter-parameter urinalisa, salah satunya adalah leukosit. Pemeriksaan alternatif untuk mengetahui kondisi dari leukosit dapat dilakukan dengan uji carik celup atau dipstik. Namun, tidak menutup kemungkinan untuk memperhatikan parameter pemeriksaan urine lainnya. Dalam uji dipstik, leukosit dapat dideteksi pada parameter leukosit carik celup melalui adanya reaksi antara reagen dengan enzim leukosit esterase yang terkandung di dalam sel netrofil. ${ }^{6}$

\section{Delanghe dan Speeckaert} menjelaskan bahwa tahapan preanalitik yang tidak tepat dapat mempengaruhi hasil pemeriksaan urine. Hal ini dikarenakan sampel yang akan diperiksa diperlakukan tidak baik sehingga menyebabkan perubahan kadar analit di dalamnya. Human error atau kondisi lingkungan sekitar laboratorium dapat menjadi faktor penyebab ketidaktepatan preanalitik. Salah satunya adalah penundaan pemeriksaan terhadap sampel laboratorium yang sering terjadi di fasilitas pelayanan kesehatan seperti rumah sakit. ${ }^{4}$

Hasil penelitian yang sejalan yang memperlihatkan bahwa terjadi penurunan jumlah leukosit urin akibat penyimpanan urin pernah diteliti oleh Kustiningsih, Cahyono, dan Rahmiati pada penderita Dibetes Melitus. ${ }^{7}$ Penurunan jumlah leukosit dapat terjadi akibat faktor suhu, suhu yang lebih tinggi akan menyebabkan pertumbuhan bakteri yang semakin cepat sehingga enzim dalam urine semakin cepat mengalami katalisasi. Hal ini mampu merusak sel leukosit dalam urine. Selain dari itu, penundaan dalam pemeriksaan urine pada pasien infeksi saluran kemih dapat menyebabkan pembelahan bakteri semakin cepat dan mempercepat potensi bakteri untuk mengubah urea menjadi ammonia dalam urine. Ammonia akan mengakibatkan $\mathrm{pH}$ dalam urine akan bergeser ke arah basa dan berpotensi melisiskan leukosit dalam urine. ${ }^{8}$

Pemeriksaan harus dilakukan secepat mungkin, paling lambat 1 jam setelah urin ditampung. Melakukan penundaan pemeriksaan dapat menjadi sumber kesalahan, sehingga hasil yang

Meditory | ISSN Online : 2549-1520, ISSN Cetak : 2338-1159, Vol. 7, No. 1, Juni 2019

HIm. 7 -12, http://ejournal.poltekkes-denpasar.ac.id/index.php/M 
diharapkan tidak sesuai dengan kondisi klinis pasien. Unsur-unsur berbentuk (sedimen) dalam urin mulai rusak dalam waktu 2 jam dan bila dibiarkan lama dalam suhu kamar akan terjadi lisis sel serta torak dan urin akan berubah menjadi alkalis. ${ }^{9}$

Berbeda dengan hasil penelitian yang dilakukan oleh Naid, Mangerangi, dan Almahdaly, menunjukkan bahwa tidak ada pengaruh penundaan terhadap jumlah leukosit. Penundaan urine selama 2 jam dapat menyebabkan ketidakstabilan urine sehingga terjadi pergeseran $\mathrm{pH}$ urine menjadi lebih asam atau basa tergantung kondisi pasien. Hal ini akan mempengaruhi status kimiawi urine seperti keton, urobilinogen, nitrit, dan glukosa. Sedangkan unsur sedimen urine seperti leukosit dan epitel mengalami perubahan berupa negatif palsu apabila disimpan selama hampir 2 jam. ${ }^{10}$

\section{KESIMPULAN}

Ada pengaruh penundaan pemeriksaan urine terhadap jumlah leukosit urine pada pasien infeksi saluran kemih bila dilakukan penundaan 3 jam.

\section{Daftar Pustaka}

1. Najeeb, S., Munir, T., Rehman, S., Hafiz, A., Gilani, M. and Latif, M. Comparison of Urine Dipstick Test with Conventional Urine Culture in Diagnosis of Urinary Tract Infection'. J. Coll. Physicians Surg. Pakistan Vol. 25 (2, 108-110 (2015).

2. Robinson, J. L., Finlay, J. C., Lang, M. E. \& Bortolussi, R. Urinary tract infection in infants and children: Diagnosis and management. INFECTIOUS DISEASES AND IMMUNIZATION COMMITTEE 19, (2014).

3. Utsch, B. \& Klaus, G. Urinalysis in Children and Adolescents. Dtsch. Aerzteblatt Online (2014). doi:10.3238/arztebl.2014.0617

4. Delanghe, J. \& Speeckaert, M. Preanalytical requirements of urinalysis. Biochemia Medica (2014). doi:10.11613/BM.2014.011

5. Seputra, K. P. et al. Guideline Penatalaksanaan Infeksi Saluran Kemih dan Genitalia Pria 2015. (2015).

6. Triasta, Setiabudi, D. dan Rahmadi, D. Faktor Risiko Kecurigaan Infeksi Saluran Kemih pada Anak Laki-Laki Usia Sekolah Dasar'. Sari Pediatr. 18(2), 13741 (2016).

7. Kustiningsih, Y., Cahyono, J. A. and Rahmiati, N. Pengaruh Lama Penyimpanan Urine Pada Suhu Kamar Terhadap Jumlah Leukosit Studi Pada Penderita Diabetes Mellitus',. . (2016).

8. Gandasoebrata, R. Penuntun Laboratorium Klinik. (Dian Rakyat, 2013).

Meditory | ISSN Online : 2549-1520, ISSN Cetak : 2338-1159, Vol. 7, No. 1, Juni 2019 HIm. 7 - 12, http://ejournal.poltekkes-denpasar.ac.id/index.php/M 
Bunga Dewanti, dkk., Pengaruh Penundaan Pemeriksaan Urin Terhadap Jumlah Leukosit Pada Penderita Infeksi Saluran Kemih

9. Widman, F, K. Tinjauan Klinis atas Hasil Pemeriksaan

Laboratorium. (Penerbit Buku Kedokteran. EGC, 1995).
10. Naid, T., Mangerangi, F. \& Almahdaly, H. Pengaruh Penundaan Waktu terhadap Hasil Urinalisis Sedimen Urin. 06, 212219 (2014).

Meditory | ISSN Online : 2549-1520, ISSN Cetak : 2338 - 1159, Vol. 7, No. 1, Juni 2019

HIm. 7 - 12, http://ejournal.poltekkes-denpasar.ac.id/index.php/M 